\title{
A Brief Analysis of the Hero's Withdrawing from the Business of the World in 1900
}

\author{
Jun Xu \\ English Department of Dezhou University, China \\ Email: xujun56cn@yahoo.com.cn
}

\begin{abstract}
Italian writer Alessandro Baricco in 1994. This paper mainly focuses on the spirit of withdrawing from the business of the world of 1900. His rejecting secular life, love and life manifests this, he chooses to withdraw from the business of the world due to the following reasons: he has a different value orientation; he has a unique love with the sea, ship and the piano; he fears about the uncertainty of the land and he sticks to the border in his heart. His spirit can inspire people to lead a free and happy life.
\end{abstract}

Index Terms - withdrawing from the business of the world, participating in the social life, 1900

\section{INTRODUCTION}

1900 was written in 1994, its background was the industrial revolution and European tide of immigration to America, in that time, everyone had an American dream, it mainly rethinks about the sense of worth in new time, it is an irony to the money worship, it is a masterpiece of critical realism.

1900 was found abandoned on the four stacker SS Virginian, a mere baby in a hand basket, and likely the son of poor immigrants from steerage. Danny, a coal-man from the boiler room, is determined to raise the boy as his own. He names the boy Danny Boodman T. D. Lemon 1900 (a combination of his own name, the year, and an advertisement found in the basket) and hides him from the ship's officers. During the early years of his life, 1900 comes across an advertisement for a man with the initials of T.D; however, on seeing the advertisement and possibly 1900's biological father, Danny decides not to tell 1900 the truth. Sadly, a few years later, Danny is killed in a workplace accident, and 1900 is forced to survive aboard the Virginian as an orphan. For many years, he travels back and forth across the Atlantic, keeping a low profile and apparently learning the languages spoken by the immigrants in Third Class.

The boy shows a particular gift for music and eventually grows up and joins the ship's orchestra. He befriends Max in 1926, but never leaves the vessel, even when presented with the opportunity to fashion a new life with a pretty immigrant girl. Apparently, the outside world is too "big" for his imagination at this point.

1900 is the hero of this novel; his life is a typical life of withdrawing from the business of the world. He is an orphan that abandoned by his parents and adopted by a kind coal burner in the steam ship, however the coal burner was dead in an accident when he was only a few years old, he becomes an orphan once again. 1900's extraordinary gift makes him become a self-taught piano master, but fate also let him have a deep-seated natural alert to the world of mortals, he dares not get off the ship to set foot on land, because New York's stretch of buildings and flowing crowd makes him lose himself; even if he meets a girl that love at first sight, he considers repeatedly, finally he restrains the impulse to set foot on land to find his first love, he stays in the ship forever. Until his only friend warns him that the ship will be blown, he still doesn't want to leave. With an explosion, he is buried into the sea.

There are two clues distinctly running through the novel: one is the 1900 in Max's memory, the other is that Max searches for 1900 in reality, in other words, it is the choice of withdrawing from the business of the world or participating in the social life. The author intends to make people rethink about what should people do in this world. This paper mainly discusses the choice of withdrawing from the business of the world of 1900 and his reasons, how to use it to deal with our business, work and life, makes people lead a brilliant, free and easy life.

\section{THE PERFORMANCES OF 1900'S WITHDRAWING FROM THE BUSINESS OF THE WORLD}

There are some performances of the hero who withdraws from the business of the world; he rejects something that people can't give up, such as the secular life, love, even life.

\section{A. Rejecting Secular Life}

Feng (2009) holds the opinion that in his article People love secular life, because it has a lot of things that people can't reject, for example, family, fame and money, friendship, love, these make people live happy, in other words, these are the reasons that people live for. Secular life is colorful, but when you are enjoying it, you also need to follow the secular life's rules.

He says no to the rules. When he is playing in an orchestra, he often play some melody in his mind, this make the 
band can't cooperate with him, when he is asked why not keep the regulations, he said rude words: Fuck the regulations!

He gives up money and fame. His good friend Max appreciates his music talent, he persuades him several times to set foot on land, he is also puzzled that why he refuses to get out of ship stubbornly. He hopes 1900 shows the talent to the world and gets admitted by the people, to get fame and live a good life. But to 1900, it is too far away, he can't understand the people's yearning life, therefore it doesn't attractive him. Later, the talent of 1900 is praised by the people, the father of jazz Jelly Morton believes his talent is the first; therefore he takes a challenge to 1900. Finally, 1900 wins the game and earns a great reputation. A record publisher hopes to record his music and guarantees that he will win fame and money, but his heart still calm, at last, he crashes the record, he settles the happiness that the music brings to him.

People live for the friends and family, sometimes 1900 is also yearning for this kind of life, but finally, he gives them up. He is alone, he has only one friend Max, he thinks that a friend is enough, Max often persuades him to get off the ship, and describes a very sweet family picture that everyone will admire, but he scares of that life, even at last, his friend Max takes a lot of work to find him, tells him that the ship will be blown up, he says "I will not get off, anyway, there is no one remember my name in the world, perhaps, you belong to that minority, you'd better get used to it, don't cry like a child".

\section{B. Rejecting Love}

1900 meets a girl who is simple but attractive. The day he is recording, the girl looks into through the window, when he looks into her eyes, he immediately falls in love with her, and he plays a feminine tune spontaneously, when the record finishes, he doesn't give the record to the publisher, because he doesn't allow others to put his music away from him. He hesitates repeatedly, wants to give the record to that girl, but not being fulfilled finally, he could not hide his sorrow, he is disappointed to ruin the record and throws the debris into the trash, he misses love. After the girl leaves, Max and 1900 never mention the girl again, 1900 still plays his piano but he always misses the girl in heart. Max's persuasion and the longing for love touches him, after at least twelve voyage, he finally decides to set foot on the strange land in a spring. On that day, the entire crew wave to say goodbye, he wears an overcoat Max gives him, walks off ladder slowly. But when he walks to the half of ladder, he stares at the New York City blankly; he suddenly picks his hat off and throws it out, the hat falls on the ocean between the ship and the mainland, then 1900 returns to the boat. He says to Max, "I won't get out forever. He rejects love.

\section{Rejecting Life}

Life is the most precious thing, everyone just has once, but 1900 rejects it too. At the end of the novel, Virginia is to be blown up, Max believes 1900 must be in the boat, he finds him and advises him down again "Life is immense, change life, start again"1900 explains: land is a ship too big for me. It's a woman too beautiful; it's a voyage too long, a perfume too strong. It's a music I don't know how to make, take a piano, the keys begin, the keys end. You know there are eighty-eight of them, nobody can tell you any different, they are not infinite, and you are infinite. And on these keys the music that you can make is infinite (Jiang, 2009). I like that, that I can live by. He thinks that get off the boat just like rolling out in a keyboard of millions of keys, millions and billions of keys that never end, that keyboard is infinite. And if that keyboard is infinite, that's God's piano. Max respects the choice of his friend, 1900 dies together with the boat, he rejects life. It reflects his love and passion for music. Meanwhile, it shows his fear towards life and depression about the reality. He prefers to die rather to live meaninglessly.

\section{SOME REASONS THAT 1900 WITHDRAWS FROM THE BUSINESS OF THE WORLD}

Firstly, he has a different value orientation. 1900 has a different value orientation, this different value formation often come from different living environments. 1900 is born and lives in a floating boat, the boat is limited, there is only 2000 passengers in one trip, despite there are the rich, the poor, the smugglers and so on, but compared with the urban population, especially like New York ,2000 people is very limited. His experiences in the boat, including his seeing, his hearing becomes limited. Thus, he has a limited demand and value evaluation, it performed that people give the object a positive or negative judgment through whether it meets the need or not. In other words, if a thing or phenomenon has certain properties or performance can meet some need (material needs and spiritual needs)of people, it has a positive meaning, and is considered useful and valuable, thus people often evaluate something from the need, the people's need is the value evaluation and inner basis. Different people have different needs, the same people have different need at different times, and thus, its value evaluation will change with the person and time. When an object can meet the need that people will give a positive evaluation; when it can't, it will be given a negative evaluation. 1900 gives up the ideal life in other people's eyes, precisely because they have different value evaluation and needs. Just as Fan(2010) described that people are bound up in the material civilization of city life, they yearn for fame, status, money, but 1900 enjoys the infinite heartfelt happy that playing piano brings to him, happy or not happy, this is his value orientation.

Secondly, he has a unique love with the sea, ship and the piano. People often lose themselves in the endless pursuit of material, but 1900 knows what is his needs exactly, sea, piano, ship are all of his need, they are just like his hometown, lover and home. He is abandoned in Virginia, this may suggest that his fate will connect with the sea, they have a lot of 
things in common, and only the sea can understand his loneliness. 1900 is autistic, the sea is like a concert hall with tide applause, a sound box with echo, a considerate audience, a silent sound field, it's like a hometown in his heart. The God gives him the talents to play piano, he knows everything of it, he can play it in his own mind, he can describe everything through the music and he looks the piano just like his lover. The ship is not only a vehicle, it loads millions of dream of people go to the other side of the ocean, he is the king of the ship, he doesn't have identity card or any other things that can certify his existence, the ship can protect him forever, it just likes his home.

Thirdly, he fears about the uncertainty of the land. The sea, piano, and ship are what he loves; the land and city are what he fears. He thinks land people waste a lot of time wondering why. Winter comes, they can't wait for summer; summer comes, they're living dread of winter. That's why people are never tired of travelling, with chasing some places where there's always summer far away, but that doesn't sound like a good bet to him. He fears about the city, because in that entire sprawling city there is everything except an end ( $\mathrm{Li}, 2005)$. Just the streets, there were thousands of them! There are too many choices, this make him crazy. When max asks him why he doesn't set foot on the land, he answers: "Land? Land is a ship too big for me. It's a woman too beautiful; it's a voyage too long, a perfume too strong. It's a music I don't know how to make. I could never get off this ship. At best, I can step off my life. After all, I don't exist for anyone. You're an exception, Max, you're the only one who knows I'm here. You're a minority, and you better get used to it. Forgive me, my friend, but I'm not getting off." Besides, in 1900's eyes, you just couldn't see the end of the city. It wasn't what 1900 saw that stopped him. However, it was what 1900 didn't see. In all that sprawling city there was everything except an end. There was no end. What 1900 did not see was where the whole thing came to an end. As a result, he stayed and choose to the life with the piano, ship and sea.

Fourthly, he sticks to the border in his heart. People will come across a lot of borders in their lives, when people are encountering them, everyone must want to step over them, maybe, 1900 is the only one that can stick to the border in his heart, he gives up the right to come across the border. 1900 sticks to the border in his heart with a unique way, his border is in the ship and in the keys of the piano and he expresses his talents in the keys and makes a great glory. Either the ship or the keys, they are not infinite. His happiness of life comes from playing infinite music in limited keys. It's just like the ship; its space is between prow and stern. He has a clear border in his heart; he says to Max "Take a piano. The keys begin, the keys end. You know there are eighty-eight of them, nobody can tell you any different. They are not infinite. You are infinite. And on these keys the music that you can make is infinite. I like that and that I can live by. You get me up on that gangway and you're rolling out in front of me a keyboard of millions of keys, millions and billions of keys that never end, and that's the truth, Max. That they never end. That keyboard is infinite. And if that keyboard is infinite, then on that keyboard there is no music you can play. You're sitting on the wrong bench. That's God's piano." He knows his position and border; he sticks to it in his life. The Legend 1990 just explains a philosophy view in another language. 1900 is lonely and the only thing that can company him is music. He can not imagine what life will become if he goes ashore and he does not know the significance of his life. So he chooses to stay in the ship and perishes alongside the floating city on the sea.

\section{What CAN PEOPLE LEARN From 1900}

In ancient times, participating in the social life referred to three levels: life self-cultivating; family-regulating; state-ordering; then the land great governed, but in modern times, it mainly refers to a state of mind, the so-called participating in the social life is looked success or failure, right or wrong, lost or gain as the basic principles to get along with people. People must work with a positive and initiative attitude; people want to use limited life to get great achievement. People live to do things for themselves or for society, people can see the sunrise and sunset everyday, but how many times you can see this scene in your lifetime? So people must cherish everything and never waste of time. Spring flower and autumn moon is fun; cold winter, hot summer is ok. People must live full and meaningful, it is beneficial to people and also good for ourselves. People need a positive and effective state of mind and do everything as a big celebration, don't be pessimistic, people need do everything step by step.(Guo, 2009) In ancient times, withdrawing from the business of the world was isolated from the world of mortals, they were often solitary and hid in the mountains, pursued the inaction and the inner peace, but in modern times, the so-called withdrawing from the business of the world is to respect life and the objective law, people must try their best to do everything, people must get along with people with a gentle state of mind, don't pursuit perfect, stand a little higher, see a bit further, see some things lighter. To get along with people, you must not look the interests too heavy, you need have a gentle attitude, when a person participates in the social life too deep, as time passes, he will lost into tedious life, look the actual benefits overweight, then he is always realistic and constrained by prejudice, it is difficult to get out of it, he can't have great work. And at this time, people need a spirit of withdrawing from the business of the world. Just as what we learn from 1900, what he faces is the endless temptation and endless choices. 1900 abandons the entire world to choose the music. For him, it is a comfort, but also content; is stubborn, but also happiness to choose music as his lifetime company. Only in the music can he feel free.

\section{CONClusion}

1900 has become the last legend of 20th century, this legend only exists in literary works now, it is difficult to realize 
in real life, people can do now is handle the mentality of withdrawing from the business of the world and participating in the social life. It is a contradictory but complementary problem, people must participate in the social life, then people can withdraw from the business of the world, at the same time, people must withdraw from the business of the world, then people can participate in the social life. Life is rich, colorful and varied, so every mode of existence is correct. In a word, withdrawing from the business of the world or participating in the social life is just a way of life. What can people do now is not only withdrawing from the business of the world but also participating in the social life, people must involve in social reality actively and transcend beyond the world, people need transcend the reality but don't escape from realty, people must work step by step but not fall in it, people must not seek to withdraw from the business of the world, but we also need a little indifferent to fame and wealth. Perhaps the highest level of withdrawing from the business of the world and participating in the social life is a Chinese saying: The junior hermit practices in the wild; the medium in the crowd; the senior in the court.

\section{REFERENCES}

[1] Feng, H.J. (2009). Instability or persistence: The Legend of 1900. Youth Literator, 6, 46-52.

[2] Fan, R. (2010). Music in 1900's life: The Legend of 1900. Dian Ying Wen Xue, 11, 5-11.

[3] Guo, Y. (2009). Analysis of 1900's survival psychology from the film The Legend of 1900. Film Review, 5, 25-31.

[4] Jiang, L. (2009). Crossing life--Analyzing The Legend of 1900 from psychological aspect. Film Review, 24, 51-54.

[5] Li, D. (2005). No end in the city--Reflection from the film The Legend of 1900. Guangxi Jiao Yu, 36, 12-16.

Jun Xu was born in Binzhou, China in 1956. She majored in English Linguistics and Literature in the department of Foreign Studies, Liaocheng University, China in 1976-1979 and completed equivalent M.A. degree courses on English Linguistics and Literature in Shandong University, Jinan, China in 2002. Supported by Chinese State-funded students studying abroad Project, she was a full-time Visiting Scholar in School of English Study, Nottingham University, UK in 2002-2003.

She is currently an associate professor and the Director of the School of Foreign Languages, Dezhou University, Shandong, China. She has written "Study on analysis of Students' Speaking Error and PETS-Instruction of Students' Speaking Error Analysis in English Speaking Teaching", Vladivostock, Russia: Intelligent Potential of Advanced Education-Development of Russian Far East and Asia-Pacific Development, 2009; "Experiencing in Glamorous Language World", Yantai, China: Journal of Yantai Education Institute, 2004; "Backwash Effect on Current High School English Teaching in light of NMET", Shandong Enterprise Education, 2007; Translation works: The Cambridge Illustrated History of British Theatre', Shandong Pictorial Press. 2006. Her research interests include cross-cultural communication and English language teaching. 